\title{
Constraints Faced by Farmers in the Use of ICTs District Prayagraj, (U.P.)
}

\author{
Antim $^{1 *}$, E. P. K. Das ${ }^{1}$ and Sunil Kumar ${ }^{2}$ \\ ${ }^{1}$ Sam Higginbottom University of Agriculture, Technology, and Sciences (SHUATS), \\ Allahabad, India \\ ${ }^{2}$ Department of Agriculture, IIAST, Integral University, Kursi road Lucknow, Uttar Pradesh, \\ India \\ *Corresponding author
}

\section{A B S T R A C T}

\section{Keywords}

Electronic media, Information

Technology,

Information and

Communication

Technology (ICT),

Agricultural

Technology

Article Info

Accepted:

20 December 2020

Available Online:

10 January 2021
Most studies focus on evaluating critical adoption success factors while broadly discussing the failure to adopt information technology but now days, ICT has become one of the most important enabling forces for development. Previous studies have recognized the importance of the adoption processes. However they fail to define the principles and theory required in order to manage them successfully. This study is focused attempt to contribute to a better understanding of adoption problems of ICT in agriculture. It also highlights the constraints as an emerging field focusing on the enhancement of agricultural and rural development through improved information and communication processes. The study concludes that "End Users" are the key factor in defining the needs and critical success factors for ICT development and implementation.

\section{Introduction}

In order to transform agriculture sector into information driven, modern and competitive sector, the role of Information and Communication Technology (ICT) cannot be overruled. They provide faster and newer ways of delivering and accessing information. The people working in the agriculture sector are least equipped with proper tools to deal with rapidly changing agriculture production scenario and international competitive environment. At present, the ratio of the farmers to the extension workers is 1000:1, also the existing transfer of technology mechanisms and extension programmes run by the government departments are slow and in many cases ineffective in view of the vast gaps between the research and farmers linkages. This is partly due to inadequate use of new areas of information dissemination in various development programmes. Apart from the conventional methods of information dissemination like traditional extension 
methods, electronic and print media, the recent foray into information gateway is the initiative of ICT tools in Agriculture and allied sectors. The introduction of ICT helps in upgrading the information at least cost while substantial anecdotal evidence on the impact of mobile phones on farmers has been reported in the media, rigorous demonstration of its potential has only recently been attempted. The constraints in using mobile phone by respondents are presented in the table given below. To know the constraints faced by farmers in use of ICT the present investigation "A Study on impact of ICT (Electronic Media) on the adoption of improved agricultural practices in district Prayagraj (U.P.)

\section{Materials and Methods}

The study was conducted in the Prayagraj district of Uttar Pradesh. The block Chaka was selected for the selection of respondents. Those farmers only, who were receiving agricultural information technology i.e. television radio and mobile were treated as respondents for the present study. 10 respondents were selected from each of the selected villages, making the total sample size of 300 respondents with proportionate random sampling method.

Table communicates that the major constraint was lack of the difficulty in clarification if any doubt arises in using ICT tools. This may be because of lack of human resources well versed in using ICT tools for the organizations and limited resources. The problems of lack of practical exposure for ICT tools and lack of locally relevant information of ICT tools were expressed by many of them. The problem of network availability has been encountered by farmers may be because the government has not still recognized the importance of ICT in agriculture. This trend also might be attributed to the reason that the importance of ICT has not been recognized by policy makers or they might have felt some more important areas to be given thrust for finance other than ICTs. The problem of cost of ICT tools may be due to lack of human resources for proper maintenance of ICTs and insufficiency of financial resources for the repairing and maintenance of ICT tools.

Table.1 Constraints faced by farmers to use ICT in agriculture

\begin{tabular}{|c|l|c|c|}
\hline S.No. & \multicolumn{1}{|c|}{ Constraints } & \multicolumn{2}{c|}{ Responses } \\
\cline { 3 - 4 } & & $\begin{array}{c}\text { Frequency/ } \\
\text { Per centage }\end{array}$ & Rank \\
\cline { 2 - 4 } & Infrastructural constraints & $122(67.77)$ & I \\
\hline 1. & Fluctuating telecommunication network & $88(48.75)$ & IV \\
\hline 2. & Lack of electric supply & $60(33.35)$ & V \\
\hline 3. & Lack of maintenance & $116(64.17)$ & II \\
\hline 4. & Lack of access to internet & $108(60.00)$ & III \\
\hline 5. & Non availability of recommended inputs in the market & $23(12.92)$ & VI \\
\hline 6. & Non availability of regular ICT services on agriculture & & \\
\hline & Technical Constraints & $55(30.83)$ & VIII \\
\hline 1. & Inability to operate mobile phone & $67(38.33)$ & VII \\
\hline 2. & Inability to read text SMS and e-mail (Illiteracy) & $21(11.67)$ & IX \\
\hline 3. & Inability to understand language of service provide & \\
\hline
\end{tabular}




\begin{tabular}{|c|l|c|c|}
\hline 4. & Inability to use GPRS and 3G/4G services & $161(89.17)$ & I \\
\hline 5. & Complexity in using internet and video messages & $116(64.17)$ & IV \\
\hline 6. & $\begin{array}{l}\text { Non availability of details information given in text SMS } \\
\text { format }\end{array}$ & $102(56.67)$ & V \\
\hline 7. & Difficulty in making use of given theoretical information & $126(70.00)$ & III \\
\hline 8. & $\begin{array}{l}\text { Lack of practical knowledge about given new } \\
\text { recommendation }\end{array}$ & $101(56.25)$ & VI \\
\hline 9. & Lack of timely availability of agriculture information & $140(77.50)$ & II \\
\hline & Economic Constraints & $90(50.00)$ & II \\
\hline 1. & High cost of multimedia mobile phones & $76(42.08)$ & III \\
\hline 2. & High cost of telecommunication network services & $102(51.67)$ & I \\
\hline 3. & Inability to purchase recharge cards & $54(30.20)$ & VIII \\
\hline & Miscellaneous Constraints & $93(51.67)$ & VI \\
\hline 1. & Services on mobile phone & $110(61.25)$ & I \\
\hline 2. & Lack of satisfactory solution of individual problem & & \\
\hline 3. & Absence of personal contact (trust) with information & $98(54.58)$ & V \\
\hline provider & Result of earlier recommendation was not satisfactory & $98(54.58)$ & V \\
\hline 5. & Adoption of prescribed technologies by farmer is very low & $109(60.83)$ & II \\
\hline 6. & Busy network of Kisan Call Centre & $106(58.75)$ & IV \\
\hline 7. & Lack of confidence in provided service / information & $88(48.75)$ & VII \\
\hline 8. & Lack of availability of timely and accurate marketing & $107(59.58)$ & III \\
\hline 9. & Price Information & $105(58.58)$ & I \\
\hline $\mathbf{1 0 .}$ & Call drop problem & $107(59.58)$ & III \\
\hline $\mathbf{1 1 .}$ & $\begin{array}{l}\text { Lack of knowledge about availability of agricultural } \\
\text { advisory }\end{array}$ & & \\
\hline
\end{tabular}

The figures shown in parenthesis is percentage

The farmers reported the problems of languages might be because of non provision of regular updating of antivirus and provision of filters. There is problem of insufficient number of ICT tools in the organizations, which may be due to inadequate budget allotted for it. The problem of technical and infrastructure problems while using ICTs was expressed by the farmers. Technical constraint might be because of lack of human resources skilled in the usage of ICTs and infrastructure constraint might be because of non provision of infrastructure needed or supporting infrastructure. for example the need for UPS during power failures for the computers. The problem of lack of training to employees for using ICTs was expressed and this could not be provided because of lack of time and also insufficient budget. They also reported the problem of lack of latest ICT infrastructure and this is due to insufficient funding for ICT. Farmers also reported the problem of erratic electric supply and this might be because of poor service by service providers of internet and lower bandwidth. The problem of fear to adopt technology of ICT equipment was expressed by many and this may be because the personnel are not trained or exposed on the usage of different equipment or the personnel may not be aware of the recent updates.

The study concluded that the economic impact of mobile is likely to be strongest 
when the absence of inadequacy of existing telecommunications facilities acts as a barrier or bottleneck to private economic activities, but also when enough, other infrastructure exists to permit the effective use of telecommunications. Information asymmetries are a well documented source for inefficient functioning of markets; farmers can bridge or alleviate the information gap at three major stages of the agricultural cultivation cycle by the use of mobile phones.

\section{References}

Batte M.T., E. Jones, and D. Schnitkey. (1990): Computer Use by Ohio Commercial Farmers. American Journal of Agricultural Economics, 72:935-45.

Christensen M.C. (1992): Exploring the limits of the technology S-Curve. Part I: Component technologies, and also; Christensen M. C., 1992, Exploring the limits of the technology S-Curve. Part II: Architectural technologies, Operation Management 1, no. 4, Fall.

Cragg P. (1996): Adoption of the Internet by Small Firms http://www.scu.edu.au/sponsored/auswe b/ausweb96/business/cragg/.

Gelb E. (1998): A Computer in the milking Parlor Paper 9805. The center for Agricultural economic Research. Rehovot, Israel.

Hosmer L.T. (1995): Trust: The Connecting Link Between Organizational Theory and Philosophical Ethics. Academy of Management Review, 20:379-403.
Mahajan V., E. Muller and F.M. Bass. (1990): New Product Diffusion Models in Marketing: A Review and Directions for Research. Journal of Marketing, 54:1-26.

Ministry of Agriculture and Rural Development, Planning Authority. (1999): Agricultural Production forecast 1999-2005 (Hebrew).

Ptak C.A. and E. Schragenheim. (1999): ERP: tools, techniques and applications for integrating the supply chain. The St. Lucie Press/APICS Series on resource management, ISBN 1-57444-270-8.

Rapley K. (1997): Accounting for the value generated from innovation, Journal of Knowledge Management, ISSN 1367 3270, Vol. 1, Number 2, pp 157- 160.

Rogers E.M. (1995): Diffusion of Innovations - 4th Edition, New York: The Free Press.

Srorey J. and E. Barnett. (2000): Knowledge management initiatives: Learning from failure, Journal of Knowledge Management, ISSN 1367 - 3270, Vol. 4, Number 2. pp. 145- 156.

Thompson S. and S.T. Sonka. (1997): Potential Effects of Information Technologies on the Economic Performance of Agricultural and Food Markets. American Journal of Agricultural Economics, 1997:657-662.

Varela T.F.E. and E. Rosch. (1994): The embodied mind: Cognitive science and human experience, MIT Press (Cambridge).

\section{How to cite this article:}

Antim, E. P. K. Das and Sunil Kumar. 2021. Constraints Faced by Farmers in the Use of ICTs District Prayagraj, (U.P.). Int.J.Curr.Microbiol.App.Sci. 10(01): 3042-3045. doi: https://doi.org/10.20546/ijcmas.2021.1001.354 